\title{
Impact of Studying Foreign Language Preparation Class on Academic Achievement in Turkish Public and Private Selective Schools
}

\author{
Mustafa Bahar \\ Faculty of Education, Fatih University, Hadimkoy, 34500, Buyukcekmece, Istanbul, Turkey
}

\begin{abstract}
Language preparation classes are an important way of teaching a foreign language with a one-year intensive program. However, they are also criticized for delaying academic studies of students. Preparation classes were also a widespread application in Turkey, where many thousands attended for one year at the start of their high school education. Science high schools in Turkey get the highest achieving students in statewide university entrance exam. Science high school students were divided into school two groups after High School Entrance Examination, and one group (1692) studied one-year language preparation and the other (1333) started their academic school year direct. Correlations and means between their HSEE entrance scores and University Entrance Exam (UEE) scores were compared to see whether there was a difference in achievement at the end of high school between the two groups. Significance of difference between correlations was calculated with Fisher's $z$ test and significance of the difference between means was calculated by independent samples t test. Analyses showed the group that studied one-year preparation class had lower correlations between their HSEE and UEE scores. As for the differences between means, although 2005 group had higher scores compared to the other group in the beginning, this difference decreased at the national university entrance exam conducted after four years of high school study.
\end{abstract}

Index Terms — science high school, language preparation class, academic achievement, $\mathrm{Z}$ scores

\section{INTRODUCTION}

Because of the benefits it brings, many countries including Turkey have emphasized teaching a foreign language to its students. In a study by Thomas, Collier and Abbot (1993) comparing students participating in the (language) immersion program and the comparable group, language immersion program students scored at least as well as, and to some extent better than, students who were not in the program. It was the same for the mathematics test and immersion program students outperformed comparison group after two years of immersion program participation (Thomas et al., 1993).

A study by Hernandez (2007) attributed low achievement of minority Hispanics in the United States not to English, language other than their native language, but to students' socio-economic status (Hernandez, 2007). Genesee (2004) indicated that second language did not impair first language. Learning a foreign language did not decrease academic achievement in native language (Sparks \& Ganschow, 1991). To the extent that overall GPA may be a global measure of native-language aptitude, the finding that overall academic achievement is the best predictor of foreign-language achievement is consistent with Sparks and Ganschow (Sparks and Ganschow, 1991, 1993a, 1993b).

There is plenty of evidence showing studying a foreign language benefits learners' academic achievement (Curtain \& Pesola, 1994; Bankston and Zhou, 1995; Collier 1992; Armstrong and Rogers, 1997; Taylor-Ward 2003; Chow, 2004), brain development (Dumas, 1999), reading development (Garfinkel \& Tabor, 1991; Taguchi, Takayasu-Maass \& Gorsuch, 2004), cognitive development (Lee, 1996; Genesee, and Cloud,1998; Lee, 1996) and higher levels of executive control (Bialystok, Craik \& Freedman, 2007). Adesope, Olusola, Lavin, Thompson, \& Ungerleider, (2010) analysed 63 studies after carefully screening 154 articles about bilingualism and cognition. All the outcome measures produced statistically detectable mean effect sizes in favor of bilingualism associated with cognitive outcomes (Adesope et al. 2010). A cognitive variable [academic achievement] explained the greatest proportion of the variance in foreign language achievement (Onwuegbuzie, Bailey \& Daley, 2000).

Bialystok, Craik, Klein, and Viswanathan (2004) found that lifetime bilinguals are more resistant to age-related losses of certain cognitive abilities than monolinguals and the age of dementia onset for the bilinguals was 4 years later than it was for the monolinguals. Kotik-Friedgut identified SLA variables that influence the recovery of bilingual brains from traumas (2001). Schwartz mentioned switching to second language when native language speaking was impaired (Schwartz, 1994). Kim et al. showed brain activities for native language and second languages were different (Kim et al., 1997). They had findings consistent with distinct roles for the anterior and posterior language areas in the processing of human language. Sheng, McGregor \& Marian found bilingualism may enhance paradigmatic organization of the semantic lexicon in two (native and second) languages (Sheng, McGregor \& Marian, 2006). Knowing a foreign language also helps learn another language (Abu-Rabia \& Sanitsky, 2010). 
Now that there is no doubt about benefit of knowing a foreign language, the question of how and when to teach it arises. Many start at very early ages, some start at primary school and some at middle schools. But, for some it has to be delayed until high school or university studies as is evident in university language preparatory schools.

\section{Foreign language at high school}

Teaching a foreign language at high schools is a widespread practice all over the world. Yet, styles vary as regards the type of education given. Some countries give extensive one-year foreign language education, whereas others prefer to embed it into the curriculum.

According to the regulations of Ministry of National Education among the five basic aims of science high schools is to provide students with a foreign language that will help them make scientific researches and follow scientific and technological developments (Ministry of National Education, 1999). In preparation classes, other lessons did not have effect on passing the class. If the student was not successful in language, he/she repeated the class for one more year (Ministry of National Education, 1999). Education period in the high schools concerned was 3 years after preparation class. As of 2006, the regulation was changed and these schools were turned into 4-year-schools, incorporating language learning into the curriculum.

Until 1997 preparation classes were devised to be held just after 5 year primary school education. A central entrance examination was held by the Ministry of National Education in order to select students after 5-year primary school education. Those students were exposed to a one-year preparatory class that includes intense foreign language lessons followed by three years of middle school foreign-language medium education. With the start of 8-year compulsory education, after 1997, the preparatory year was replaced between 8 year primary education and secondary education. This however affected language learning in Turkish schools.

Although language learning was supposed to start at $4^{\text {th }}$ grade, even students of selective schools began to learn a foreign language (predominantly English) after the age of 14, which was evident with the application of preparation year before secondary schools. High school education was extended from three to four years and the application of preparatory year was terminated with law 184, beginning with 2005-2006 academic year, (Tebliğler Dergisi, 2005). High schools with preparation classes had 24-hour English lessons besides having other lessons. Among those lessons were Turkish and physical education. Science high schools taught 20 hours English and 4 hours of secondary foreign language at preparation classes (Soner, 2007)

The system was changed on the grounds that preparation year was not accepted as a class. Besides, it was claimed that research conducted with students, parents, English teachers, and guidance counselors revealed that preparatory year should be finalized because being educated on a foreign language intensively takes students away from other lessons and causes adaptation problems to other lessons in the following years (Kefeli, 2008).

In a study carried out by Kefeli parents of students from high schools who studied preparation class and parents of those did not were interviewed. Families of students from preparation classes said they were advantaged in passing preparation classes at universities. Similarly those who studied preparation classes were said to be better achievers in foreign language (English) and didn't have to spare more time for learning English (Kefeli, 2008). On the other hand, some saw the preparation 'a time to rest', which was also uttered by students of preparation classes in personal interviews.

There is significant difference between studying and not studying a preparatory class at high school and foreign language readiness. There is significant difference between studying at a preparatory class and skipping it as regards foreign language achievement (Özdemir \& Ünal, 2008). In a study covering a sample of 81 students, students graduating from foreign language oriented high schools were more successful in language learning than those who were not (Aydin, 2006).

The strongest predictor of a school's academic performance was the socioeconomic status of students, followed by the foreign language enrollment, and the number of ELLs in a school. A school's academic performance as measured by the API used in California was significantly correlated with the percentage of students enrolled in foreign language classes (Sung, Padilla \& Silva, 2006). However, foreign language appears to be more of a result in this case than a cause, since high achieving schools emphasize foreign language as reflected by the high socioeconomic status and more foreign origin language teachers.

On the other hand, there is also considerable negative attitude towards teaching in a foreign language, which is supported by some evidence. No matter how good they are at foreign language in terms of grammar and vocabulary, language competence in a foreign language may be a handicap while expressing their own ideas for students (Kocakulah, Ustunluoglu \& Kocakulah, 2005). The quantitative and qualitative findings indicate that students who studied "the Energy Unit" in the native language were capable of giving more scientifically acceptable explanations than those who studied in a foreign language (Kocakulah, Ustunluoglu \& Kocakulah, 2005). Johnstone and Selepeng (2001) indicated that students who learn science in a second language lose at least 20 percent of their capacity to reason and understand the process (Johnstone \& Selepeng, 2001).

Foreign language preparation classes in Turkey

In Turkey, national education policies have greatly been influenced by governments of the respective times. Sometimes it has been influenced by nationalism, at other times it has been decided by internationalism. Turkey is among the countries where a language other than Turkish is considered a foreign language. Constitution of Turkey 
allows for only Turkish as official language and no western language is spoken by the public. That is, English is a foreign language in Turkey. Even if Turkish is the national language of education, English gets hold of a non-official status in Turkey and it adopts a crucial place in every educational institution (Kefeli, 2008).

However, survey findings revealed the communicative language teaching proposed by the MoNE did not seem to have the expected impact on teachers' classroom practices because classroom activities were largely based on traditional methods of teaching (Kırkgöz, 2007). In a study carried out by Ergüder (2005) students at high school language preparation classes had similar problems (Ergüder, 2005). One reason for students' failure to learn may be that they do not feel the need of the English language in their daily life yet, and they delay learning the English language until adulthood when they become to be forced to learn English due to, say, professional needs (Karahan, 2007). Yet parents of the students do not favour abolishing preparatory school year on the grounds (that) their sons or daughters will not be able to learn a foreign language.

Another point to make is when student studying preparation class at high school enter preparation classes at universities they are less motivated to study than those who did not study preparation class at high school (Madran, 2006). Evidence from university preparation English language classes showed students from high schools that taught more English did not have more positive attitude towards English language classes compared to general high school students, who get very little English language education (Ertan, 2008).

\section{Selective high schools and national exams}

Turkish selective schools get their students via nationally (officially held) recognized nationwide exams. High School Entrance Exam (HSEE) is an exam with four subtests (Turkish, Social Sciences, Natural Sciences and Mathematics). About a million students enter these exams and students are placed according to their scores and preferences of the type and place of the high school. This type of selection clears the problem of equity met elsewhere such as in the UK where there is potential for discrimination and inequity (Coldron, Willis \& Wolstenholme, 2009). The best selective schools can mainly be grouped into four school types. In the first place are social sciences high schools, the number of which is only 31 as of 2012 (Uysal, 2012). Most of the highest scoring students enter science high schools, which enroll about 6000 students. There are also teacher training schools whose number reached 298 in the year 2011-2012. Then, come Anatolian high schools enrolling the highest number of selected students around the country and therefore with the lowest scores among the best school types. All of the science high schools prepare their students for university entrance exam, without which science high school education is almost useless. University Entrance Exam (UEE) of Turkey is the sole medium to enter a university except for some arts colleges. UEE is a compulsory exam taken yearly by all graduates of high schools, and anyone who has finished a high school can enter these exams.

There is almost no study regarding science high schools and language although there is abundance of studies regarding Anatolian high schools. Nor is there any adequate research on preferring or disapproving the application of the preparatory year. Therefore, the requirement to fill the gap of the research related to the current program and termination of the preparatory year application is needed to be satisfied (Kefeli, 2005). This study sheds the first light on science high schools, language classes and their academic achievement at the same time.

\section{METHOD}

\section{Participants}

This study included 3025 students who enrolled in science high schools from among the successful 105.000 students - the exam was taken by 917.000 eight-grade students - after taking HSEE (High School Entrance Exam), a statewide exam conducted by the Ministry of National Education. These highest achieving students were divided by school administrations into two groups so that a group studied foreign language preparation classes for one year and the other group started $9^{\text {th }}$ class direct, a sign that shows the confusion about the relationship between preparation classes and academic achievement. Even if this division did not stem from an experimental design, it served to test the difference between two groups.

Since HSEE is the only exam that can be taken to enter selective schools, students taking HSEE are motivated enough, a factor positively influencing the reliability of the exam. The exam is prepared by the sole state authority that prepares the test according to the curriculum, which considerably ensures the validity of the exam. A student enters these exams only once, at $8^{\text {th }}$ grade.

University entrance exams (UEE) are statewide standard exams compulsory to enter higher education. They have the highest reliability coefficients and they are completely content-based even if there are occurrences of items ( 1 or 2 in a total of 120 questions) outside the curriculum. Both UEE tests (2005 and 2006) are taken very seriously as both are used to place students in their respective educational institutions and they are the only means for placement as Turkey is a country where placement is made by the hand of the state. Both tests are based on the curriculum determined by the Ministry of National Education.

Procedure

UEE-2005 and the UEE-2006 are independent of each other and means and standard deviations of both exams for all the population were retrieved from the official site of the governmental institution administering the exam. Both exam had four subtests testing the same curriculum. The test of 2002 HSEE consisted of four subtests each consisting of 25 questions comprising of a total of 100 questions. All 3025 students took the same HSEE exam in 2002. 
First, scores of students who gained a place at high schools were gathered and then these scores were matched with scores of university entrance examination results of the same students. 1333 of these data matched and then the same high school entrance exam (HSEE) scores were matched with university entrance examination of 2006.1692 of these data matched with HSEE data using the variable that differentiated between the students who entered for the first time and others who entered more than once. Later, descriptive statistics for both groups were determined. There was difference between the means of two groups due to different number of questions. Because students took different tests one earlier year and the following year, scores were turned to z scores, which standardize scores and distributes students according to others. As around one and a half million students take the test each year, turning into $\mathrm{z}$ scores distributed individuals in the two groups perfectly. Then, significance of difference between the $\mathrm{z}$ scores of two groups was calculated with independent samples t-test. Other than this, results of 2002 high schools entrance exam and 2005 and 2006 university entrance exam results were correlated for both groups. Significance of difference between correlations was calculated using Fisher's Z test. There was no missing data.

\section{RESULTS}

First, descriptive statistics and then correlations and differences in means were calculated.

TABLE 1.

TEST MEANS AND STANDARD DEVIATIONS FOR COMPLETE GROUPS

\begin{tabular}{llllllll}
\hline UEE 2005 & Mean & Total & Std. Dev. & UEE 2006 & Mean & Total & Std. Dev. \\
\hline Turkish & 20,2 & 45 & 12,5 & Turkish & 14,7 & 30 & 7,2 \\
Social sciences & 11,3 & 45 & 11,0 & Social sciences & 12,3 & 30 & 7,3 \\
Mathematics & 7,5 & 45 & 11,5 & Mathematics & 8,5 & 30 & 8,4 \\
Natural sciences & 3,9 & 45 & 9,6 & Natural sciences & 2,7 & 30 & 5,6 \\
\hline
\end{tabular}

\section{Correlations between the HSEE tests and UEE tests}

TABLE 2.

\begin{tabular}{|c|c|c|c|c|c|c|c|c|}
\hline HSEE Tests & $\begin{array}{l}2005 \\
\text { Turkish }\end{array}$ & $\begin{array}{l}2006 \\
\text { Turkish }\end{array}$ & $\begin{array}{l}2005 \\
\text { Math }\end{array}$ & $\begin{array}{l}2006 \\
\text { Math }\end{array}$ & $\begin{array}{l}2005 \text { Soc. } \\
\text { Sci. }\end{array}$ & $\begin{array}{l}2006 \text { Soc. } \\
\text { Sci. }\end{array}$ & $\begin{array}{l}2005 \text { Nat. } \\
\text { Sci. }\end{array}$ & $\begin{array}{l}2006 \text { Nat } \\
\text { Sci. }\end{array}$ \\
\hline Turkish &, 421 &, 313 & & & & & & \\
\hline Mathematics & & & ,662 &, 534 & & & & \\
\hline Soc. Sci. & & & & & ,487 & ,403, & & \\
\hline Nat. Sci & & & & & & & 629 & ,490 \\
\hline & & & & $\begin{array}{l}{ }^{*} \mathrm{p}<.00 \\
05 \mathrm{~N}= \\
06 \mathrm{~N}=\end{array}$ & & & & \\
\hline
\end{tabular}

After correlations were calculated using SPSS 15, significance of difference between these correlations was sought. $\mathrm{SE}$ was computed to be 0,03816 . Z value for the difference between correlations of Turkish tests was 3,197 , much larger than 2,58 cutoff point for significance at the .01 level. The difference between mathematics tests correlations was 5,136 which is again a lot larger than 2,58 at the significance level ,01. There was significant difference between social sciences tests at the, 05 level $(2,62)$. As for natural sciences test, there was significant difference $(5,372)$ between natural sciences tests correlations of 2005 and 2006 exams.

\section{Mean differences for subtests between the two groups of HSEE takers}

TABLE3.

INDEPENDENT SAMPLES T TEST RESULTS FOR HSEE SUBTEST MEAN DIFFERENCES FOR 2005 AND 2006 GROUPS 2005
$(\mathrm{~N}=1333)$ $2006(\mathrm{~N}=1692)$

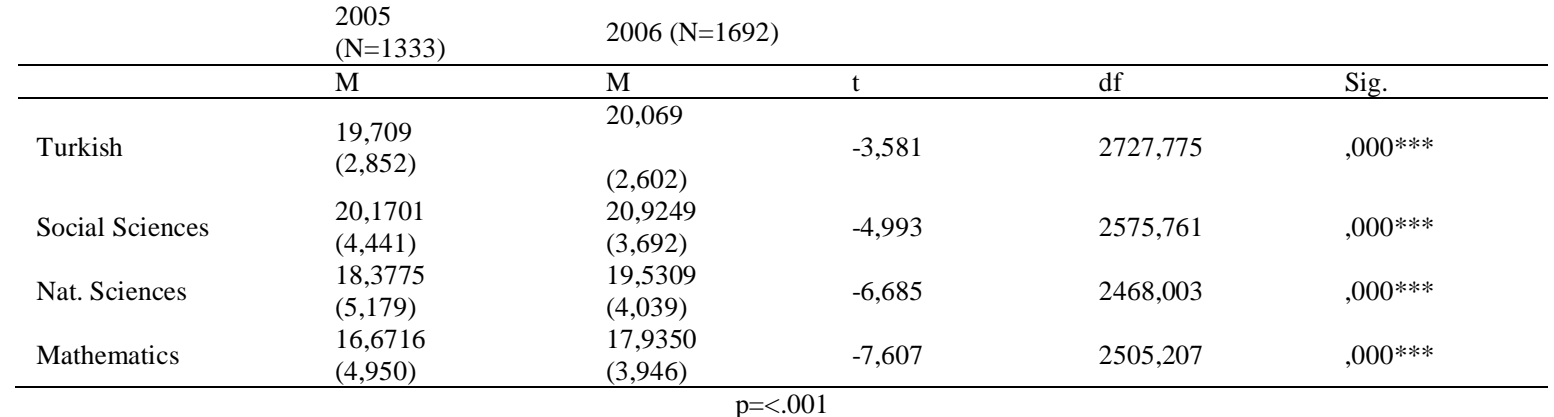

Independent-samples t-test was conducted to evaluate the hypothesis that two groups have different scores. The language (Turkish) test was significant, $\mathrm{t}(2728)=-3,581, \mathrm{p}<.001$, As the standard deviations are different two groups have unequal variances. The second group (2006) had higher Turkish means than the group that had the exam in 2005. The means of both groups in the language test are statistically different. Because variances are different in two groups, 
unequal variances assumed, is used as seen from the table t value is $-3,581$, which means students taking 2006 exam achieved higher in 2002 OKS exam.

Independent-samples t-test results for social sciences scores showed the difference between tests was significant, $\mathrm{t}(2576)=-4,993, \mathrm{p}<.05$. The second group (2006) had higher social sciences means than the group that took the exam in 2005. Independent-samples t-test conducted to see differences between 2005 group and 2006 group showed the test was significant, $\mathrm{t}(2468)=-6,685, \mathrm{p}<.001$ The second group (2006) had higher HSEE natural sciences means than the group that had the exam in 2005. As for mathematics scores, the test was significant, $t(2505)=-7,607, p<.001$. The second group (2006) had higher HSEE mathematics means than the group that had the exam in 2005.

Mean differences for subtests between the two groups of UEE takers

TABLE. 4

INDEPENDENT SAMPLES T TEST RESULTS FOR UEE SUBTEST MEAN DIFFERENCES FOR 2005 AND 2006 GROUPS

\begin{tabular}{|c|c|c|c|c|c|}
\hline & $\begin{array}{l}2005 \\
(\mathrm{~N}=1333)\end{array}$ & \multicolumn{4}{|c|}{$2006(\mathrm{~N}=1692)$} \\
\hline & $\mathrm{M}$ & $\mathrm{M}$ & $\mathrm{t}$ & df & Sig. \\
\hline Turkish & $\begin{array}{l}1,236 \\
(0,635)\end{array}$ & $\begin{array}{l}1,196 \\
(0,645)\end{array}$ & $-1,709$ & 2877,6 & ,088 \\
\hline Social Sciences & $\begin{array}{l}0,600 \\
(1,406)\end{array}$ & $\begin{array}{l}0,710 \\
(1,100)\end{array}$ & $-2,348$ & 2472,982 &, $019 * *$ \\
\hline Nat. Sciences & $\begin{array}{l}3,015 \\
(1,135)\end{array}$ & $\begin{array}{l}3,441 \\
(1,001)\end{array}$ & $-10,785$ & 2672,799 &, $000 * * *$ \\
\hline Mathematics & $\begin{array}{l}2,509 \\
(0,676)\end{array}$ & $\begin{array}{l}2,171 \\
(0,429)\end{array}$ & 15,901 & 2143,234 &, $000 * * *$ \\
\hline
\end{tabular}

An independent-samples t-test was conducted to evaluate the hypothesis that two groups have different UEE Turkish scores. The test was insignificant, $\mathrm{t}(3023)=-1,706, \mathrm{p}<.05$, As the standard deviations are very close two groups have equal variances. There was no significant difference between the means of both groups. The second group (2006) $(\mathrm{M}=1,236, \mathrm{SD}=0,635)$ and the first (2005) group $(\mathrm{M}=1,196, \mathrm{SD}=0,645)$ had similar means.

The test for social sciences scores showed the difference between scores was significant, $\mathrm{t}(2348)=-2,348, \mathrm{p}<.001$. The second group (2006) $(\mathrm{M}=0,600, \mathrm{SD}=1,407)$ had higher social sciences means than the group $(\mathrm{M}=0,710, \mathrm{SD}=1,100)$ that had the exam in 2005. With regard UEE natural sciences scores, the difference was significant, $t(2673)=-10,785$, $\mathrm{p}<.001$. The second group (2006) $(\mathrm{M}=3,441, \mathrm{SD}=1,000)$ had higher UEE natural sciences means than the group $(M=3,015, S D=1,135)$ that had the exam in 2005. Independent-samples t-test for the difference between mathematics scores showed the test was significant, $\mathrm{t}(2143)=15,901, \mathrm{p}<.001$. The first group $(2005)(\mathrm{M}=2,509, \mathrm{SD}=0,676) \mathrm{had}$ higher UEE mathematics means than the group $(M=2,171, S D=0,429)$ that had the exam in 2006.

\section{DISCUSSION}

Correlations between HSEE scores and UEE scores were higher in 2005 than in 2006 for all subtests. This clearly indicates that students' achievements are influenced in different ways, and probably for the negative, if they delay their academic studies. Interestingly enough, correlation in native language test was low contrary to other studies, although other evidence indicates positive effects of foreign language on mother language. As mathematics test is correlated with general ability, it was the least affected in correlation.

Independent samples t-tests showed that scores in HSEE scores between 2005 and 2006 entrants were different. The groups that were chosen for preparation classes (the group to enter the exam in 2006) had higher means in all test types of HSEE. That is, the high achieving group was chosen to study language preparation class.

After four years of education things have changed. Independent samples t test showed, of the four subtests students took, there was no difference between the two group means in language test results of UEE. The difference favoring second group in HSEE disappeared in UEE exam. As for social sciences test, UEE results favored the second group as it did in HSEE exam. So, the group continued its advantage. Again in natural sciences test, the group that had the UEE in 2006 continued its advantage over the group that had the exam 2005 because t test results showed, as in HSEE scores, second (2006) group had higher means in natural sciences test. Mathematics test results show that first group gained an advantage over the second group which achieved higher in the high school entrance exam.

Even if a comparison should be made with caution, the results of this study contradict with some research which say; "Most research show that, not only do foreign language immersion students perform as well as their nonimmersion peers on standardized tests, but often, outscore them" (Caldas \& Boudreaux, 1999). A similar difference exits with what Thomas, Collier and Abbot (1993) said: It was the same for the mathematics test and immersion program students outperformed comparison group after two years of immersion program participation. (Thomas, Collier and Abbot, 1993).

\section{CONCLUSION}


Bilingual programs are especially important for older students who, because of the limited time left in their schooling, cannot afford to pause in learning social studies, math, and science while acquiring English as a second language (Collier, 1992; Krashen, 1996). Though bilingualism is not the same as foreign language proficiency, both are supposed to bring benefits in achievement to the speaker. This study cautions us to be careful about how to handle the issue of another language.

Sacrificing academic studies to learn a foreign language for one year seems to harm student future prospects. Results show delaying studies related to academic achievement may adversely affect achievement in students. This study showed the group that studied one year language class scores lower compared to other group. Because students are placed to universities with regard to their relative positions to all the other students, second group had a disadvantage in placement exam. The second group was not able to make up for the difference between academic achievement scores. So, instead of allocating a year for language preparation it might be more logical to incorporate learning a foreign language into the curriculum. Another cause of the problem encountered here may be the age of the student group was 15 , a late time to learn a foreign language spending extensive time.

Lower correlations in the second group imply language studies should be hand in hand with academic studies. Personal interviews show students see language preparation year as a year of rest, which distances students from core courses. It is possible that students who entered by studying hard were affected most by the delay.

Although language learning is hailed by all as a means for many benefits, it should be made clear that it does not undermine other studies putting learners at a disadvantage relative to other students. Evidence indicates it could be beneficial to teach language including academic content to ensure learners do not lag behind others.

\section{REFERENCES}

[1] Abu-Rabia S. Sanitsky E. (2010). Advantages of bilinguals over monolinguals in learning a third language. Bilingual Research Journal 33(2), 173-199. doi: 10.1080/15235882.2010.502797.

[2] Adesope O. O., Lavin T, Thompson T. \& Ungerleider, C. (2010). A systematic review and meta-analysis of the cognitive correlates of bilingualism. Review of Educational Research, 80(2), 207-245. doi:10.3102/0034654310368803.

[3] Armstrong, P., \& Rogers, J. (1997). Basic skills revisited; The effects of foreign language instruction on reading, math, and language arts. Learning Languages, 2(3), 20-31.

[4] Aydın, S. (2006). İkinci dil olarak İngilizce öğrenimindeki başarı düzeyinin bazı değişkenlere göre incelenmesi. Atatürk Üniversitesi Sosyal Bilimler Enstitüsü Dergisi, 8(2), 273-285 Retrieved 19-04-2011 from http://edergi.atauni.edu.tr/index.php/SBED/article/view/366/360.

[5] Bankston, C. L., III \& Min Zhou. (1995). "Effects of Minority-Language Literacy on the Academic Achievement of Vietnamese Youth in New Orleans." Sociology of Education, 68, 1-17. Retrieved 21-04-2011 from http://www.jstor.org/stable/2112760.

[6] Bialystok, E., Craik, F.I.M., \& Freedman, M. (2007). Bilingualism as a protection against the onset of symptoms of dementia. Neuropsychologia, 45, 459-464. Retrieved 07-05-2012 from http://www.yorku.ca/coglab/wpcontent/uploads/2009/08/Bialystok_Craik_Freedman.pdf.

[7] Bialystok, E., Craik, E, Klein, R., \& Viswanathan, M. (2004). Bilingualism, aging, and cognitive control: Evidence from the Simon task. Psychology and Aging, 19, 290-303. Retrieved 05-05-2012 from http://www.yorku.ca/coglab/wpcontent/uploads/2007/11/Bialystok_Craik_Klein_Viswanathan.pdf.

[8] Caldas, S., \& Boudreaux, N. (1999). Poverty, race, and foreign language immersion:predictors of math and English language arts performance. National Network of Early Language Learning, 5(1), 4-15.

[9] Chow, H. P.H. (2004). The Effects of Ethnic Capital and Family Background on School Performance: A Case Study of Chinese-Canadian Adolescents in Calgary. The Alberta Journal of Educational Research, 50(3), 321-326.

[10] Coldron, J., Willis, B.\& Wolstenholme, C. (2009) Selection by attainment and aptitude in English secondary schools. British Journal of Educational Studies. doi: 10.1111/j.1467-8527.2009.00435.x 578(3), pp 245-264.

[11] Collier, V. P. (1992). A synthesis of studies examining long-term language minority student data academic achievement. Bilingual Journal, 16, 1987-212. citeseerx.ist.psu.edu/viewdoc/download?doi=10.1.1.28.9670\&rep=rep1\&type=pdf.

[12] Curtain, H. \& Pesola. C. A. B. (1994). Languages and Children: Making the Match: Foreign Language Instruction for An Early Start Grades K-8. Longman (New York).

[13] Dumas, L. S. (1999). Learning a Second Language: Exposing Your Child to a New World of Words Boosts Her Brainpower, Vocabulary, and Self-Esteem. Child, 72(74), 76-77.

[14] Ergüder, I. (2005). Problems anatolian and super high school preparation class students face in learning English. Anadolu lisesi ve süper lise hazırlık sınıfı öğrencilerinin ingilizce öğreniminde karşılaştıkları sorunlar. Unpublished doctoral dissertation. Dokuz Eylul University.

[15] Ertan, B. A. (2008). İngilizce hazirlik sinifi ögrencilerinin İngilizce dersindeki güdülenmelerinin ve inançlarinin incelenmesi [Investigation of university students' motivation for learning English and their beliefs about learning it]. Unpublished master's thesis. Ankara University.

[16] Garfinkel, A. and Tabor, K. E. (1991). Elementary School Foreign Languages and English Reading Achievement: A New View of the Relationship. Foreign Language Annals, 24: 375-382. doi: 10.1111/j.1944-9720.1991.tb00483.x.

[17] Genesee, F. \& N. Cloud. (1998). Multilingualism is Basic. Educational Leadership, 62-65.

[18] Genesee, F. (2004). What do we know about bilingual education for majority language students? In T.K. Bhatia \& W. Ritchie (Eds.), Handbook of Bilingualism and Multiculturalism (pp. 547-576). Malden, MA: Blackwell. http://www.psych.mcgill.ca/perpg/fac/genesee/HDBK\%20BILINGUAL\%20EDUCATION.pdf. 
[19] Hernandez, C. (2007). Home Language Use and Hispanic Academic Achievement: Evidence from Texas High Schools. Penn McNair Research Journal. 1(1), 1-30

[20] Johnstone, A. \& Selepeng, D. (2001). A language problem revisited. Chemistry Education: Research and Practice in Europe, 2(1), 19-29. http://www.uoi.gr/cerp/2001_February/pdf/05Johnstone.pdf.

[21] Karahan F. (2007). Language attitudes of Turkish students towards the English language and its use in Turkish context. Çankaya Üniversitesi Fen-Edebiyat Fakültesi,Journal of Arts and Sciences, 7.

[22] Kefeli, H. (2008). Exploring the perceptions of teachers, students, and parents about the new 4-year anatolian high school english program. Phd. dissertation. METU.

[23] Kim, K. H. S., Relkin, N. R., Lee, K., \& Hirsh, J. (1997). Distinct cortical areas associated with native and second languages [Abstract-Electronic version], Nature, 388, 171. http://www.artsci.wustl.edu/ bio3411/kim.pdf.

[24] Kirkgöz, Y. (2007). English language teaching in Turkey: policy changes and their implementation. RELC Journal, $38,216$. DOI: $10.1177 / 0033688207079696$.

[25] Kocakulah S., Ustunluoglu E., and Kocakulah A. (2005). The effect of teaching in native and foreign language on students' conceptual understanding in science courses. Asia-Pacific Forum on Science Learning and Teaching, 6(2), Article 2.

[26] Kotik-Friedgut, B. (2001). A systemic-dynamic lurian approach to aphasia in bilingual speakers [Electronic version], Communication Disorders Quarterly, 22, 100-1 10. Retrieved from http://cdq.sagepub.com/content/22/2/100.full.pdf+html.

[27] Krashen, S.D. (1996). Under attack: the case against bilingual education. In Linguistics, language acquisition and language variation: Current trends and future prospects. ED. Alatis E. J., Straelhe, A. C., Ronkin, M. \& Gallenberger, B. Georgetown university round table an languages and linguistics.

[28] Lee, P. (1996). Cognitive development in bilingual children: A case for bilingual instruction in early childhood education. $\begin{array}{lllll}\text { Bilingual Research } & \text { Joumal, } & \text { 20(3-4). } & 499-522 . & \text { Retrieved }\end{array}$ citeseerx.ist.psu.edu/viewdoc/download?doi=10.1.1.112.9315\&rep=rep1\&type=pdf.

[29] Madran, D. (2006). Üniversite İngilizce hazırlık ögrencilerinin basarı güdülerinin, basarıları üzerindeki etkisi [The effects of achievement motivation on the academic achievement of university English preparation class students]. Unpublished masters thesis. Dokuz Eylül Üniversitesi, Izmir.

[30] MoNE (1999). Milli Eğitim Bakanlığı fen liseleri yönetmeliği[Regulation for Science High Schools]. 1999. Retrieved from http://mevzuat.meb.gov.tr/html/50.html.

[31] Milli Eğitim Bakanlığı Tebliğler Dergisi Talim Terbiye Kurulu Başkanlığı 68, $2005 . \quad$ Retrieved from http://dhgm.meb.gov.tr/yayimlar/dergiler/Tebligler_Dergisi/2573.pdf.

[32] Onwuegbuzie, A. J., Bailey, P. \& Daley, C. E. (2000). Cognitive, affective, Personality, and demographic predictors of foreignlanguage achievement. The Journal of Educational Research, 94(1), pp. 3-15.

[33] Özdemir, M. \& Ç., Ünal. (2008). Eğitim fakültelerinde ortak ders olarak okutulan yabancı dil derslerinde öğrencilerin bilişsel hazırbulunuşluk düzeylerinin akademik başarıya etkisi. Ahi Evran Üniversitesi Kırşehir Eğitim Fakültesi Dergisi (KEFAD) 9(1), 13-22, Retrieved from http://kefad.ahievran.edu.tr/archieve/pdfler/Cilt9Sayi1/JKEF_9_1_2008_13_22.pdf.

[34] Schwartz, M. S. (1994). Ictal language shift in a polyglot. J. Neurol. Neurosurg. Psychiat. 57(121), Retrieved from http://www.ncbi.nlm.nih.gov/pmc/articles/PMC485055/pdf/jnnpsyc00031-0135a.pdf.

[35] Sheng, L., McGregor, K. K. \& Marian, V. (2006). Lexical-semantic organization in bilingual children: evidence from a repeated word association task. Journal of Speech, Language, and Hearing Research 49, 572-587 doi:10.1044/1092$4388(2006 / 041)$.

[36] Soner, O. (2007). Past and present of foreign language education in Turkey. A proposal. Türkiye'de yabancı dil eğitiminin dünü bugünü Öneri.7(28), .397-404. Retrieved from http://uvt.ulakbim.gov.tr/uvt/index.php?cwid=9\&vtadi=TPRJ\%2CTTAR\%2CTTIP\%2CTMUH\%2CTSOS\%2CTHUK\&c=goo gle\&ano=76121_d88e5fbe2358f9cddae1ac2b0783966d.

[37] Sparks, R. L., \& Ganschow, L. (1991). Foreign-language learning differences: Affective or native language aptitude differences? Modern Language Journal, 75, 3-16. $\quad$ Retrieved 17-07-2012 from http://engrammetron.net/engrammetron/resources/psychophysiology-restricted/folder.2005-1219.7227140290/Sparks_Ganschow1991.pdf/view?searchterm=None.

[38] Sparks, R. L., \& Ganschow, L. (1993a). The impact of native language learning problems on foreign-language learning: Case study illustrations of the linguistic coding deficit hypothesis. Modern Language Journal, 77, 58-74. Retrieved from http://www.jstor.org/stable/329559.

[39] Sparks, R. L., \& Ganschow, L. (1993b). Searching for the cognitive locus of foreign-language learning difficulties: Linking first and second-language learning. Modern Language Journal, 77, 289-302. Retrieved from http://www.jstor.org/stable/329098.

[40] Sung, H., Padilla, A. M., Silva, D. M. (2006). Foreign language education, academic performance, and socioeconomic status: a study of California schools. Foreign Language Annals, 39(1), 115-130.

[41] Taguchi, E., Takayasu-Maass, M. \& Gorsuch, G. J. (2004). Developing reading fluency in EFL: How assisted repeated reading and extensive reading affect fluency development. Reading in a Foreign Language, 16(2), Retrieved 12-05-2012 from http://www.nflrc.hawaii.edu/rfl/October2004/taguchi/taguchi.html.

[42] Taylor-Ward, C., J. (2003). The relationship between elementary school foreign language study in grades three through five and academic achievement on the iowa tests of basic skills (ITBS) and the fourth-grade louisiana educational assessment program for the 21 st century (LEAP 21) test. Unpublished doctoral dissertation. Louisiana State University.

[43] Tebliğler Dergisi, June 2005, No:2573, volume:68.

[44] Thomas, W., Collier, P. V., \& Abbot, M.(1993). Academic achievement through Japanese, Spanish, or French: The first two years of partial immersion. The Modern Language Journal 77, p: 170-179. http://www.thomasandcollier.com/Downloads/1993-Su_MLJ_v77-2_Thomas-Collier-Abbott.pdf.

[45] Uysal, R. (2012). Sosyal Bilimler Liseleri[Social Science High Schools]. Retrieved from http://www.kariyerpenceresi.com/index.php?yazarlarimiz,4,3/sosyal-bilimler-liseleri.html. 
Mustafa Bahar was born in Konya, 1971. Studying at the department of Teaching English as a Foreign Language, the author graduated from Bosphorus University in 1995. He finished master of arts at educational sciences in 1999 at Y1ldiz Technical University, specializing in educational leadership and earned a Phd at educational sciences in Istanbul University, specializing in academic achievement.

Worked as a language teacher for 3 years and started working as an item development specialist at a publication company for 3 years. He co-authored reading, grammar and test books, three of which are Revealing Advanced English Grammar, Deep into Meaning and Quiz Master. He worked as head of language teaching department for 13 years and at the same time headed a committee of language teaching and testing materials, namely books and periodicals. He has been working at Fatih University since 2010 at Faculty of Education, department of Measurement and Evaluation. His interest areas include foreign language testing, classroom assessment, item development, academic achievement and Item Response Theory.

Dr Bahar is a member of Association for Educational Assessment-Europe 